\title{
Knowledge spillover through foreign direct investment in textile industry
}

\section{Horas Djulius*, Juanim Juanim and Ina Ratnamiasih}

Faculty of Economics, Universitas Pasundan, Bandung-40116, Indonesia

Email: horasdjulius@unpas.ac.id

Email: juanim@unpas.ac.id

Email: inaratnamiasih@unpas.ac.id

*Corresponding author

\begin{abstract}
The purpose of this study is to identify whether the foreign direct investment can prompt the occurrence of knowledge spillover on textile companies that was caused by demonstration effect, labour turnover, as well as vertical linkage. The research method used is a mixed method. The result of quantitative approach shows that foreign direct investment indeed prompts the occurrence of knowledge spillover in the textile industry, and the labour turnover causes this. On the other hand, the result of qualitative approach shows that innovation in the textile industry, for the most part, is caused by demonstration effect that was shown by the competitor.
\end{abstract}

Keywords: foreign direct investment; FDI; knowledge spillover; textile industry; mixed method.

Reference to this paper should be made as follows: Djulius, H., Juanim, J. and Ratnamiasih, I. (2018) 'Knowledge spillover through foreign direct investment in textile industry', Int. J. Economic Policy in Emerging Economies, Vol. 11, Nos. $1 / 2$, pp.12-25.

Biographical notes: Horas Djulius is an Assistant Professor of Faculty Economics, Universitas Pasundan. He is currently the Head of Economics and Development Study Department's Laboratory. He teaches econometrics, research methodology and managerial economics in both undergraduate and postgraduate programs. His research interests' focus on knowledge spillover as has been started from his $\mathrm{PhD}$ dissertation on 2005. Currently, he is continuing such research topic to the intersection between macro and micro perspective on knowledge management, using the qualitative or mixed research method.

Juanim Juanim completed his undergraduate degree from the Faculty of Economics, Universitas Pasundan Bandung in 1995. He received his Master and PhD from the University of Padjadjaran Bandung in 2003 and 2010, respectively. He currently serves as Vice Dean for Academic Affairs of the Faculty of Economic at Universitas Pasundan Bandung, Indonesia, and he is also an Associate Professor. He has teaching experience of more than 15 years in the areas of operation management, marketing management, and research methodology. His areas of research interests are operation management and branding management. 


\begin{abstract}
Ina Ratnamiasih completed her undergraduate degree and Master degree at The Department of Management, University of Padjadjaran Bandung. She graduated the Doctoral program at Department of Management Engineering, Institute Technology Bandung in 2015. As a Lecturer at the Faculty of Economics, Department of Management, Universitas Pasundan, she is actively doing research and writing in international journals and conference proceeding. She teaches human resource management, performance measurement, leadership, introduction to management, and business ethics at Universitas Pasundan.
\end{abstract}

This paper is a revised and expanded version of a paper entitled 'Knowledge spillover through foreign direct investment in textile industry' presented at SIBR-Thammasat 2015 Conference, Bangkok, 4-6 June 2015.

\title{
1 Introduction
}

Research on foreign direct investment (FDI) had long entered a discussion about indirect aspects related to the main objective: capital and other resources. The interaction between local and foreign companies had affected many aspects. FDI proves its importance to economic development through capital investment, new knowledge, and opportunities for spillovers in the form of technology, production and knowledge (Franco and Kosovska, 2011). Foreign companies often can increase their investment not only on production activities but also on R\&D activities (Banri et al., 2010) so that indirectly creating spillover chance. Indonesia is categorised as a country in its initial stage to industrialisation with a relatively low quality of the human resource (Jacob, 2006) which potentially becomes the bottlenecks to technology transfer. This kind of situation is common in most of Indonesia's industry, especially in the textile industry. The textile sector is one of the sectors that have been penetrated by the foreign investors (Jacob, 2006).

Textile performance contributes the economic growth in Indonesia. The textile industry has hold $2.18 \%$ contribution to gross domestic product and $8.01 \%$ on processing industry in 2010 (BPS, 2008). The non-oil and gas export commodity that gives the biggest contribution for over the past 20 years is textile. It contributes $12.72 \%$ to the national manufacturing export sector excluding oil and gas (Hermawan, 2011). This industry also absorbs many labour force directly and indirectly. However, the growth of textile industry in Indonesia that was driven by foreign investment is still relatively small compared to other developing countries like India, Vietnam, and Bangladesh.

The rapid growth of the textile industry has pushed the growth of labour force. The existence of FDI has stimulated the mobility of foreign workers to Indonesia, which are employed by the local company, and vice versa. This activity has led to knowledge transfer. Kemme et al. (2009) stated that the government policy that could increase industry to attract foreign investment often caused by these activities. They provide a relatively spillover on domestic economic that was gained through an increase in output and employment. Other contributions were technology enhancement (Kemme et al., 
2009; Tambunan, 2011), company capability (Tambunan, 2011), and technical skill (Kemme et al., 2009). Ledesma (2002) found that the accumulated knowledge had a positive effect on the export from origin countries. In short, knowledge from outside has a strong positive impact on the competition level.

In the case of Indonesia, multinational companies hold a significant role as the source of new knowledge through subcontract (Tambunan, 2011; Rugraff and Hansen, 2011), labour transfer (Tambunan, 2011), outsourcing, licensing and franchising (Rugraff and Hansen, 2011). The research result by Tambunan (2011) showed that FDI did not automatically prompt technology enhancement but needed the support of local companies' readiness to absorb technology. In other word, the larger the technology absorption capacity in local firms, the higher the profit from the FDI.

The biggest centre for national textile is found on Java Island and among them is Metropolitan Bandung in which the number of labour is vast. So that the workers of the domestic textile companies obtain knowledge spillovers, the local company needs to prepare the knowledge absorption, at both a micro and macro level. Therefore, it is important to conduct research about factors affected the knowledge spillover within the domestic industry, especially the textile sector.

\section{Literature review}

\subsection{Foreign direct investment}

For developing countries, FDI holds a significant role in pushing the industrial growth in the country, especially in Indonesia. The result related to FDI role in pushing the development of textile industry shows a positive outcome. FDI plays a role in supporting the company needs on capital and technology (Saggi, 2002; Banri et al., 2010). On the other hand, there are findings regarding the adverse effects of FDI as reported by Aitken et al. (1996), Aitken and Harrison (1999), Martins (2006), Heyman et al. (2007) and Žilinske (2010). Besides, in macro economy level, there are doubts about FDI contribution on economic development (Banri et al., 2010). Nevertheless, the presence of foreign investors that shows more advanced technologies lead to the increased productivity in local companies through knowledge spillover and competition. Therefore, the spillover in the form of technology and knowledge from foreign firms are often considered as basic factors that contribute to rapid economic development (Banri et al., 2010).

The profit from knowledge overflow has been recognised by many researcher such as Banri et al., 2010; González and González, 2012; Ledesma, 2002; Kemme et al., 2009. According to Zhang et al. (2010), the spillover produced from FDI has two limitations. Firstly, they have many unknown aspects by the local companies, and secondly their diversity of foreign companies themselves.

Furthermore, the limitation of local companies related to knowledge spillover is the condition of passive companies in spillover process and forgetting the learning process that occurs. However, this limitation, as reported by Zhang et al. (2010), can be decreased by considering local business linkages, local strategic alliances, and recruiting policy, so that FDI can produce useful knowledge spillover for local companies. 


\subsection{Knowledge spillover}

The main effect of FDI in local companies is on the increasing spillover of technology, organisation, and managerial (Rugraff and Hansen, 2011). The potential spillover of the biggest FDI occurred in developing countries such as Hungary, Brazil, Indonesia and South Africa (Rugraff and Hansen, 2011). According to Rugraff and Hansen, this spillover is the most significant effect of the presence of multinational companies in economic development. Nevertheless, FDI in developing countries can decrease the sales and the level of production scale of local firms (Banri et al., 2010). The findings of Kemme et al. (2009) showed that FDI generates spillover where the spillover can increase the productivity of the IT companies, but not in textile firms. In general, the spillover in developing countries give mixed results (Rugraff and Hansen, 2011).

When foreign investors bring a large difference in terms of technology, capital, organisational, and managerial capabilities, and access to international markets with the local companies, there is a clear potential spillover to local firms. In the host country, foreign companies are often trying to protect their knowledge, management, and information to the local businesses. However, at the same time foreign investors can not hold the leak of their information to local companies (Rugraff and Hansen, 2011).

In pushing knowledge spillover from FDI, three channels encourage knowledge spillover:

1 Demonstration effect: new technologies may be too costly and risky for a domestic company because of the cost of acquiring knowledge and uncertainty of the results that can be obtained (Saggi, 2002). The technology used by the MNE will encourage domestic companies to adopt it. This demonstration effect can also occur by imitating products produced by foreign firms by paying attention to product specifications (Li et al., 2013).

2 Labour turnover: that occurs when local firms entered the competition with global markets either in their local market or abroad. This turnover prompted the company to adjust its capabilities with foreign firms (Li et al., 2013; Saggi, 2002). The second channel is related to the possibility of domestic firms hiring employees who previously worked on the MNE. The employee knows about the technology and applies it in a domestic company (Fosfuri et al., 2001; Glass and Saggi, 2002).

3 Vertical linkages: export is the third channel through which the presence of MNEs may benefit domestic companies (Aitken et al., 1997; Greenaway et al., 2004). Several studies have highlighted the positive impact of MNEs on the export capacity of domestic companies (Rhee, 1990; Aitken et al., 1997; Kokko et al., 2001). Export activities involve costs associated with the establishment of a distribution network, transport infrastructure or knowledge of consumer tastes in foreign markets (Greenaway et al., 2004). By following the process of exporting to foreign companies (through imitation or, in certain circumstances, through cooperation), domestic companies can reduce costs by entering the export market. This method may have a beneficial impact on the productive efficiency of domestic companies (Li et al., 2013; Saggi, 2002). It is also used as the final channel for domestic companies in the local market by making MNCs as suppliers (backward linkages) as well as the purchase of intermediate goods (forward linkages) as reported by Lall (1980), Clare (1996), Markusen and Venables (1999) and Saggi (2004). 
Besides the three channels, the other factors are the competition, as well as external search and search costs. (Li et al., 2013; Crespo and Fontoura, 2007) states the other factors that lead to knowledge spillover of FDI are:

- Competition is another important mechanism that encourages local businesses to increase productivity by updating on manufacturing technology and adopting better management practices (Wang and Blomstrom, 1992; Markusen and Venables, 1999).

- External search and search costs are knowledge searching process conducted by the company of the market, which is then combined with the existing knowledge to create innovations and new creations.

\section{Research methods}

This study is a research in progress as a part of the development model of knowledge spillover of FDI in the textile companies in Indonesia. The method used is study case on textile companies in Metropolitan Bandung. Data analysis is carried out with both quantitative and qualitative approaches. The analysis is first performed by using a quantitative approach; further shortcoming of this approach is equipped with a qualitative approach. Quantitative analysis is mainly used to answer two research inquiries. The first is whether there is a difference in productivity between foreign and domestic companies in the textile industry in Metropolitan Bandung. The second is whether there are knowledge spillovers from foreign companies to domestic companies.

In this study, the results of quantitative analysis then further confirmed through qualitative research. This step is done to generate an overview of the research object and reinforce the results of quantitative research. Reasons for the use of this approach are: research questions related to the question 'how and why', the researchers were not able to control the events and the research focus in certain circumstances (Yin, 1994). Required data was obtained from various sources and the evidence (triangulation or multiple sources). Triangulation is made to ensure the validity and reliability of data. In this step, the interview protocol was made in advance (Yin, 1994).

Figure 1 Knowledge spillover channels

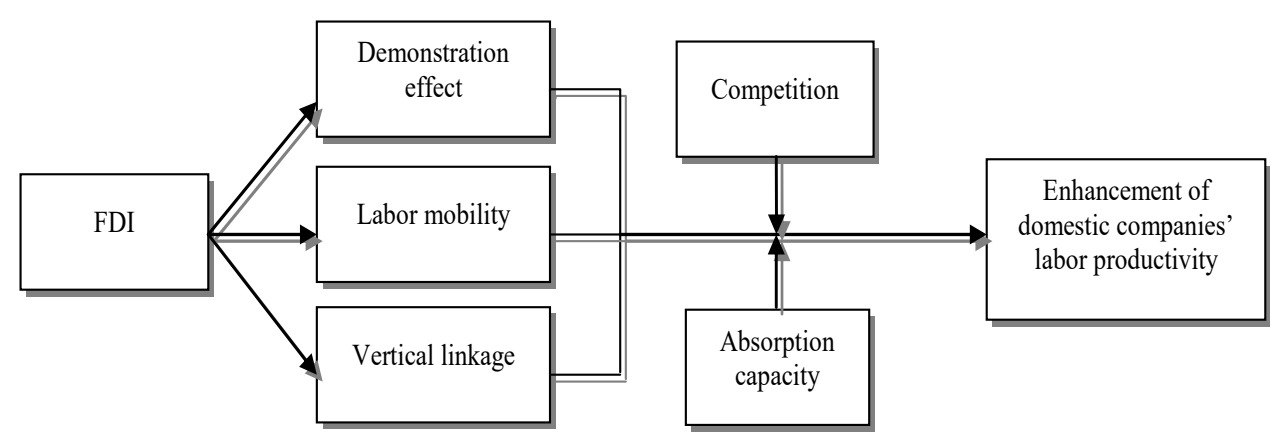




\section{Data collection method}

Data used in the quantitative approach derived from an industry survey conducted by Central Bureau of Statistics contained in unpublished tabulations of data on companies of medium and large-scale manufacturing in 2012. Some of the variables used in this study are: the identity of the company, the amount of foreign funds, the output, the number of workers in the production, the book value of machinery (capital) of production, the value of the raw material, the identity of the province location, location identity of the city/regency, and the identity of the industrial sector.

The proxy variable of knowledge spillover is the ratio of the number of workers in foreign companies (in the textile sector, in each of the four cities/regencies) to the amount of labour in the domestic companies. This variable became one of the predictors of the output of domestic companies to test the hypothesis of the knowledge spillover.

Qualitative analysis was conducted by interviewing the managers of several textile companies, both large and small. A textile company that is considered as population should meet the criteria below:

- the company cooperates with foreign investors

- the company is located in the city and regency of Bandung.

In this study, the primary data collected through interviews and questionnaires. Secondary data was collected through a variety of documents, which was derived from BPS, websites, company profiles, and annual reports. Interviews were conducted with the form of interviews with open-ended questions, focused, and semi-structured. To steer the interview, the guidelines for the interview was made. The face-to-face interview was done to collect information related to the studied variables, clarification, or to make sure about the clarity of the questions asked (Sekaran, 2000). A face-to-face interview is important that the researchers can explore the issues raised by the respondents. Interviews were conducted by the general manager and marketing manager at two textile companies in Bandung. Interviews were carried out for 1 to 1.5 hours and were assisted by a tape recorder to make sure that no information was lost.

\section{Results and discussion}

\subsection{The difference in productivity between foreign companies with domestic companies}

The results of t-test on the labour productivity of domestic companies with foreign companies can be seen in Table 1. Figures in labour productivity are obtained by dividing the output value by the amount of labour in the existing production in each company. 
Table 1 Mean difference of labour productivity between domestic and foreign firms

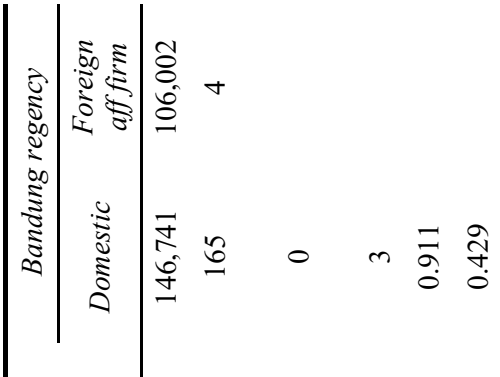

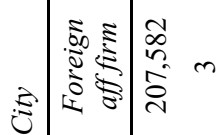

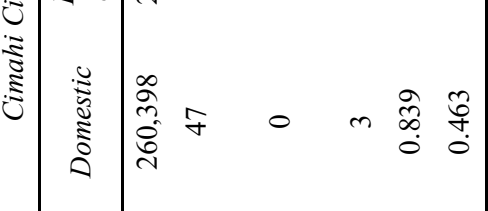

$$
\begin{aligned}
& 10
\end{aligned}
$$

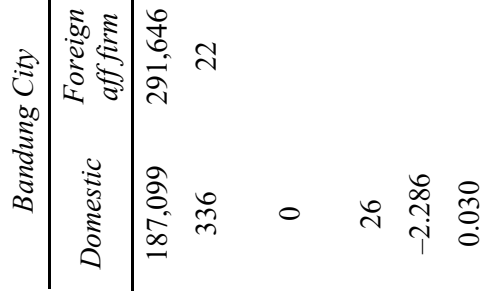

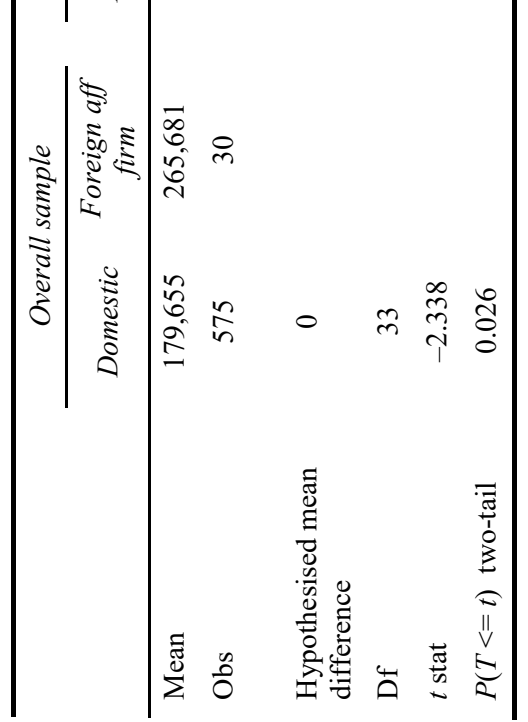


Table 1 displays the test results for the overall sample (the whole company in Metropolitan Bandung), Bandung, Cimahi and West Bandung. Testing for West Bandung Regency cannot be done because there is only one remaining foreign company from the sample selection process that had been done. The average productivity of labour for the overall sample, Bandung and Cimahi showed some foreign companies compared with domestic companies. For Bandung regency, it obtained different results where labour productivity of domestic companies was lower than the labour productivity of foreign companies.

Through the statistical test, it can be seen that the only significant difference occurred for the overall sample and Bandung alone while for Cimahi and Bandung Regency are insignificant. It appears that from the third input predictors, capital has no significant effect. This result is consistent with the findings of Maqin et al. (2012) which states that the textile companies in Metropolitan Bandung use capital (machinery production) that has a negative marginal product that needs rejuvenation. Furthermore, the alleged existence of knowledge spillover is confirmed by the results of the model estimation through Spi variables significantly influences the output of domestic companies.

Through an examination of the differences in labour productivity, it was confirmed that foreign companies obtained higher value compared to domestic companies. Both of these results can be interpreted that knowledge spillover does occur from foreign companies, which have higher labour productivity to domestic companies who have lower labour productivity. Other findings indicate that knowledge spillover occurs only in the textile companies located in Bandung, while in the area or outside the city, it showed no significant results.

Based on the interview, one of the differences in labour productivity between foreign and domestic companies is due to the quality demands. By the time the product will be exported, the company must ensure that the sale products have the number and quality standards expected by implementing quality management. The going concern of the company needs to be proved by the recognition both nationally and internationally. Most companies implement a system to obtain the certificate of ISO 14000. In foreign companies, it has been recognised, but in the local companies, productivity and quality are often processed strictly during the phase of preparation for export. After the export market can be entered continuously, gradually the management becomes disordered.

System and management in the organisation of textile companies are mostly not well organised. This situation resulted in difficulty in tracing managerial problems. Some of the consequences of bad management including management policies, especially on uncertain prices, delivery time cannot be determined, no manpower planning, so it is unknown whether or not they need new employees. This condition results in low productivity. The low productivity capability of the company is also due to the high labour costs. Currently, In Indonesia the percentage of city minimum wage rise fantastically, far exceeds the rate of inflation. On the other hand, the average minimum wage in China is lower than in Indonesia. The average employee wage in China is $\mathrm{Rp} 1.2 \mathrm{million} / \mathrm{month}$ while the wages of workers in Indonesia is $\mathrm{Rp} 1.6$ million per month to Rp 2 million per month. On the other hand, the company cannot use foreign workers too long because they are expensive. The foreign workers became an intermediary for the knowledge spillover for the improvement of the company. 
Aside from the issue of the high cost of production, there is an imported textile product issue that need to be considered. It is perceived by domestic companies that served domestic markets only. Hence, the productivity of foreign companies is higher than the productivity of local companies.

Findings related to the difference in productivity between foreign companies with domestic companies need to be confirmed further so that it can be seen Why the knowledge spillover occurs only in Bandung? Moreover, How did the knowledge spillover occur? Referring to the theory proposed by Blomström (1986) the quantitative in this study, can only measure the contribution of the labour turnover in pushing knowledge spillover. This situation occurred due to the limitations in accessing the data. Associated with the measurement of the contribution of the labour turnover in pushing knowledge spillover, then the results of the analysis can be seen in the following equation.

$$
\begin{array}{cccc}
\text { Output }=-4154788+ & 33822.095 \mathrm{Lab}+ & 0.009 \mathrm{Kap}+1.651 \mathrm{Raw}+175134.056 \mathrm{Spi} \\
\text { p-value } & (0.04) \quad\left(1.31 \times 10^{-13}\right) & (0.74) & \left(9.58 \times 10^{-18}\right) \quad(0.033) \\
\mathrm{R}^{2}=0.93 & \text { DW stat }=2.05
\end{array}
$$

The output is the value of the goods produced. Lab is the amount of labour production. Kap is the book value of the production machine. Raw is the value of the raw materials used by domestic companies. Spi is a proxy of their knowledge spillover brought by workers of foreign companies to domestic companies.

From the econometric point of view, estimation result in equation (1) is pretty good. It appears from the sign of the regression coefficient corresponding to the concept of the relationship between each predictor with the output. It also can be seen from the high value of the coefficient of determination as well as the value of the Durbin-Watson (around 2).

\subsection{Distinguishing factors of knowledge spillover in Bandung and other region}

Based on the interview, the factors that distinguish the knowledge spillover in Bandung and other region consist of labour competence factors and company readiness to adopt new knowledge. Some of the factors that lead to personal competence that caused knowledge spillover opportunities in the city than in regions are language, educational background, and association. In the city, it is likely to find a solution than outside the city of Bandung because people in the city know how to translate the language better. The next factor that led to knowledge spillover in the city is the information environment and city lifestyle where the city employees use the technology/internet access more widely.

Institutionally, there are constraints on promoting knowledge spillover. Company support on knowledge spillover to have a positive impact on productivity improvements deemed to be lacking. In other words, companies tend to not always ready to adopt new knowledge. The following comments related to the readiness of the company:

"The difficulty in obtaining cheap raw materials and machinery becomes a major obstacle that often leads to knowledge cannot be implemented. Cheap raw materials and machinery until today largely remains to be imported from China. In fact, China produces its fabrics and garments as well as an import to Indonesia." 
Comments above indicate that the companies have difficulties in implementing new knowledge due to the expensive production costs, especially the cost of raw materials and machinery. The importance of China as a competitor supported by Li et al. (2013). Li reported there was $26 \%$ of foreign companies regard local companies as a competitor company in China.

\subsection{Knowledge spillover channels of foreign companies in the domestic companies}

As previously described, the results of the quantitative analysis can only measure the contribution of labour turnover as knowledge spillover channel. Here are outlined on the three knowledge spillover channels that are demonstration effect, the labour turnover, and vertical linkage.

\subsubsection{Demonstration effect}

Demonstration effect is an imitation or duplication products or practices in the management of foreign companies by a local company. Knowledge spillover channel occurs due to the textile industry in Indonesia has two markets, they are the domestic markets and export markets. In the domestic market, the competitors are the products of China and imported used clothing. For the export market, the competitors are from China, Vietnam, Japan, and other countries. Demonstration effect is found in companies that produce garments. However, despite the demonstration effect, the garment companies still feel the weight of the competition. The following is an excerpt from the interview:

\footnotetext{
"A lot of imported products both new and second-hand clothes, both legal and illegal imports have led us to produce a more diverse product design. However, because the production costs are more expensive than competitors (especially China), the selling price is still not able to compete with garment products produced by foreign companies, especially China."
}

Based on these quotations can be seen that the effect of the demonstration can assist local companies to customise the design of products with the development of product design produced by competitors. China has a role in encouraging the occurrence of knowledge spillover in a textile company. The entry of Chinese products both legal and illegal has been encouraging employers to make similar products. In this case, the demonstration effect has encouraged local companies to boost creativity and innovation in product design.

\subsubsection{Labour turnover}

In the textile company, human resources that have many relations to knowledge spillover are top management and employees of the marketing. Spearheading who understand the demands of consumers is the marketing, while top managements usually are owners who make decisions relating to investment cooperation. From the marketing, the knowledge is presented in other sections. Export section marketing has better English skills, a better knowledge of the general corporate management that was demanded by the export companies, for example on the green product. 
Knowledge spillover may also occur due to local companies hiring employees from abroad or exporters who send their employees as part of the export-import procedures. Also, knowledge spillover can be caused by the customer requirement, namely consumer demands on product specification. In the textile companies, investors from Japan, Korea, and Taiwan are usually become the source of knowledge spillover of operation of machinery while knowledge spillover for another aspect derived from Chinese investors.

Labour turnover do not occur when the local companies do not cooperate with foreign companies or foreign investment. Therefore, the main driver of labour turnover is the market demand for textile products that is increased on overseas. High market growth will require the company to cooperate with foreign companies so that the labour turnover will increase. The labour turnover becomes the higher chances of knowledge spillover.

\subsubsection{Forward and backward vertical linkage}

The third channel of knowledge spillover is forward and backward vertical linkage. The cost of raw materials is lower than abroad, or the large overseas markets are knowledge spillover channels that occur from foreign companies on local companies. However, in the case of Indonesia, this channel is not as good as the other two channels that have been described previously. This situation occurred due to the foreign company's lack of interest in working with local textile companies in Indonesia.

Aside from the price of raw materials and semi-finished goods issues, the nonconducive political situation causes foreign investors no to be interested in cooperating with domestic companies.

This situation is illustrated by the results of interviews with the respondent:

$$
\begin{aligned}
& \text { "We feel there is still a difficult regulation. Many regulations are bureaucratic, } \\
& \text { rambling and coupled with the amount of the tax and retribution. In fact, we } \\
& \text { look forward to working more with the Japanese company because we had once } \\
& \text { learned a lot about the state of technology from Japan. However, licensing } \\
& \text { conditions and unpredictable costs have caused investors to prefer countries } \\
& \text { such as Vietnam and China." }
\end{aligned}
$$

Based on these comments, it can be concluded that the third knowledge spillover channel is not developing enough at this time. However, it is recognised that the knowledge spillover channel through vertical linkage is crucial for textile companies in Indonesia. Government support in clarity, certainty and simplicity of bureaucracy is a major factor so that these channels can be improved.

\section{Theoretical implications and future research}

This preliminary study is testing the hypothesis of the existence of knowledge spillover from foreign companies to domestic companies. However, the hypothesis tested was only partially successful due to the limitations of available secondary data. Through econometric equation, it can be deduced that knowledge spillover occurs through labour turnover. Also, this study gives a further explanation of existing theories) about knowledge spillover channels of foreign companies to domestic companies. Especially for demonstration effects channel and forward and backward linkage channel. The 
business interview stated that there are such channels in the interaction between foreign companies and domestic companies in the textile industry. Unfortunately, the macroeconomic conditions that exist in Indonesia have made those two channels no longer exist.

From previous studies, it is known that knowledge spillover does not stand alone in increasing labour productivity in domestic companies. After knowledge spillover, there are still knowledge transfer, knowledge adoption and knowledge sharing, although it is often not easy to draw a clear dividing line between the four. Therefore, it is expected the next research can continue this research up to the stage where the existence of FDI, especially in the textile industry can be useful to improve the productivity of domestic companies.

\section{Conclusions and practical implication}

The conclusion of the study are:

1 foreign companies productivity is significantly higher than domestic companies productivity

2 knowledge spillover took place from foreign companies to domestic companies that are triggered by labour turnover

3 the other factors that cause knowledge spillover are demonstration effect and forward and backward vertical linkages.

Even though the cost of production is more expensive than competitors, the local company still can not compete with products produced by foreign companies. These results would have practical implications for sustainability and improved performance of the textile industry in Metropolitan Bandung and Indonesia.

Viewed from a broader perspective, in many developed countries the textile industry has become a sunset industry, or industry that has been abandoned due to no longer provide great added value to the economy. On the other hand, Indonesia is still at the stage that requires the presence of the textile industry due to the absorption of the labour force and the added value it generates. Therefore, it still needs efforts to increase productivity and added value for the textile industry for national interest.

Several aspects need to be considered by either the company or the government to push the growth of the textile industry. Companies need to pay attention to the readiness to absorb knowledge generated from knowledge spillover. If labour can be managed well, the motivation and competence of workers can be improved. Aspects that need attention in human resource management are the process of recruitment and training. However, labour becomes a key factor for the occurrence of knowledge spillover. Nevertheless, also to improvements in the internal management of the company, it is also necessary to have the government support at least in terms of protection policy against the entry of used clothing. 


\section{Acknowledgements}

The authors are grateful to Dr. Gilbert R. Arce, Dr. Jimmy R. Soria and Dr. Antonio P. Agustin, our research partners from University of Northern Philippines (UNP) for the contribution to this article through very useful discussion during our visit to Vigan City. We are looking forward to conducting a joint research by comparing the contribution of knowledge spillover from FDI to our economies that benefit both of Indonesia and of Philippines as well as Universitas Pasundan and UNP. We are also grateful to the Ministry of Research, Technology and Higher Education, Republic of Indonesia, which has funded this research through a scheme of international research collaboration and scientific publication.

\section{References}

Aitken, B. and Harrison, A.E. (1999) 'Do domestic firms benefit from direct foreign investment? evidence from Venezuela', American Economic Review, Vol. 89, No. 3, pp.605-618.

Aitken, B., Harrison, A.E. and Lipsey, R. (1996) 'Wages and foreign ownership: a comparative study of Mexico, Venezuela, and the United States', Journal of International Economics, Vol. 40, Nos. 3/4, pp.345-371.

Banri, I., Naomitsu, Y., Zhaoyuan, X., Xiaohong, C. and Ryuhei, W. (2010) How Do Chinese Industries Benefit from FDI Spillovers?, RIETI Discussion Paper Series 10-E-026, May, pp.1-32.

Fosfuri, A., Motta, M. and Ronde, T. (2001) 'Foreign direct investment and spillovers through workers' mobility', Journal of International Economics, Vol. 53, No. 1, pp.pp.205-222.

Franco and Kozovska (2010) 'FDI productivity spillovers in regional clusters: a comparison between Poland and Romania', La Questione Agraria-Rivista dell'Associazione Rossi-Doria, Vol. 4, No. 22, pp.99-120.

González, M.R. And González, C. (2012) FDI, Labor Mobility and Knowledge Spillovers in Costa Rica.

Hermawan, I. (2011) Analisis Dampak Kebijakan Makroekonomi terhadap Perkembangan Industri Tekstil Dan Produk Tekstil Indonesia, Buletin Ekonomi Moneter dan Perbankan, April, pp.373-408.

Heyman, F., Sjöholm, F. and Tingvall, P.G. (2007) 'Is there really a foreign ownership wage premium? Evidence from matched employer-employee data', Journal of International Economics, Vol. 73, No. 2, pp.1-36.

Jacob, J. (2006) 'International technology spillovers and manufacturing performance in Indonesia', Review of Development Economics, Vol. 11, No. 3, pp.550-565, Technische Universiteit Eindhoven.

Kemme, D.M., Lugovskyy, V. and Mukherjee, D. (2009) Labor Mobility, Knowledge Transfer and Productivity Spillover: Evidence from Indian Firms, June 14.

Kokko, A., Zejan, M. and Tansini, R. (2001) Trade Regimes and Spillover Effects of FDI: Evidence from Uruguay, Weltwirtschaftliches Archiv, Vol. 137, No. 1, pp.124-149.

Ledesma, M.L. (2002) Exports, Product Differentiation and Knowledge Spillovers, Department of Economics, University Of Kent, July.

Li, H., Zhang Y.A. and Lyles, M. (2013) 'Knowledge spillovers, search, and creation in China's emerging market', Management and Organization Review, November, Vol. 9, No. 3, pp.395-412.

Markusen, J. and Venables, A. (1999) 'Foreign direct investment as a catalyst for industrial development', European Economic Review, Vol. 43, No. 2, pp.335-356. 
Martins, P. (2006) Do Foreign Firms Really Pay Higher Wages? Evidence from Different Estimators, Mimeo.

Rodríguez, C.A. (1996) 'Multinationals, linkages, and economic development', American Economic Review, Vol. 86, No. 4, pp.852-873.

Rugraff, E. and Hansen, M.W. (2011) Multinational Corporations and Lokal Firms in Emerging Economies, Amsterdam Universities Press.

Saggi, K. (2002) 'Trade, foreign direct investment and international technology transfer: a survey', World Bank Research Observer, Vol. 17, No. 2, pp.191-235.

Sekaran, U. (2000) Research Methods for Business : A Skill Building Approach, 3rd ed., John Wiley \& Sons Inc., USA.

Tambunan, T. (2011) Do Multinational Companies Transfer Technology to Local Small and Medium-sized Enterprises? The Case of the Tegal Metalworking Industry Cluster in Indonesia, Amsterdam University Press, Amsterdam.

Wang, J. and Blomström, M. (1992) 'Foreign investment and technology transfer: a simple model', European Economic Review, Vol. 36, No. 1, pp.137-155.

Yin, R.K. (1994) Case Study Research: Design and Methods, Sage Publications, London.

Zhang, Y., Li, H., Li, Y. and Zhou, L. (2010) 'FDI spillovers in an emerging market: the role of foreign firms' country origin diversity and domestic firms' absorptive capacity', Strategic Management Journal, Vol. 31, No. 9, pp 969-989.

Žilinske, A. (2010) 'Negative and positive effects of foreign direct investment', Ekonomika IR Vadyaba, Economics and Management, Vol. 15, No. 1, pp.332-336. 